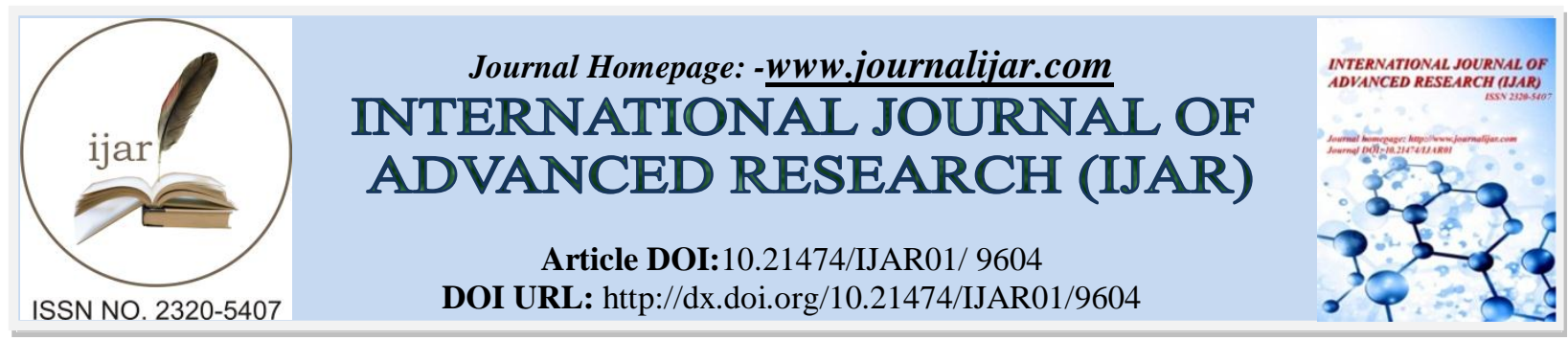

RESEARCH ARTICLE

\title{
EFFECT OF NEOADJUVANT CHEMOTHERAPY ON HORMONE RECEPTOR (ER, PR) STATUS AND HER-2/NEU EXPRESSION IN INDIAN BREAST CANCER PATIENTS: A PROSPECTIVE STUDY.
}

\author{
Saumya Singh, Vaibhav Jaiswal, Anand Kumar Mishra and Sandeep Tewari. \\ Department of General Surgery; Department of Trauma Surgery; Department of Endocrine Surgery, King George`s \\ Medical University, UP, Lucknow, India.
}

\section{Manuscript Info}

Manuscript History

Received: 20 June 2019

Final Accepted: 22 July 2019

Published: August 2019

Key words:-

Neoadjuvant Chemotherapy, Hormone

Receptor, Immunohistochemistry,

Cancer Breast.

\section{Abstract}

Objective: This study was aimed to evaluate whether neoadjuvant chemotherapy (NACT) changes hormone receptor (ER, PR) status, Her-2/neu expression in carcinoma breast and role of outcome in planning adjuvant chemotherapy.

Methods: 71 patients of locally advanced breast cancer (LABC), receiving NACT, were included. Core biopsy was done, to confirm invasive cancer, ER, PR and Her-2/neu expression before commencing NACT. Post treatment mastectomy specimen was analyzed for histopathology, ER, PR and Her-2/neu expression.

Results: Immunohistochemistry (IHC) showed that ER positivity changed from $29.6 \%(n=21)$ to $28.2 \%(n=20)$ after treatment. While $70.4 \%(\mathrm{n}=50)$ were $\mathrm{ER}^{-}$before treatment which increased to $71.8 \%$ $(\mathrm{n}=51)$ post chemotherapy $(\mathrm{p}=0.99)$. Pre-NACT, PR was positive in $31.0 \%(\mathrm{n}=22)$ which changed to $28.2 \%(\mathrm{n}=20)$ after treatment. $69 \%$ $(n=49)$ were PR before treatment which increased to $71.8 \%(n=51)$ post chemotherapy $(\mathrm{p}=0.99)$. Her-2/neu was positive in $71.8 \% \quad(\mathrm{n}=51)$ before treatment which became $70.4 \%(\mathrm{n}=50)$ post-treatment $(\mathrm{P}=0.88)$. $26.8 \%$ were $\mathrm{ER}^{+} \mathrm{PR}^{+}(\mathrm{n}=19), 66.2 \%$ were ERPR $(\mathrm{n}=47), 4.2 \%$ were $\mathrm{ER}^{-} \mathrm{PR}^{+}(\mathrm{n}=2)$ before NACT. Change in expression of hormone receptor status was noticed, $\mathrm{ER}^{+} \mathrm{PR}^{+}$decreased to $25.4 \% \quad(\mathrm{n}=18), \mathrm{ER}^{-}$ $\mathrm{PR}^{-}$increased to $69.0 \%(\mathrm{n}=49)$, ER PR ${ }^{+}$decreased to $2.8 \%(\mathrm{n}=2)$, no change was noticed in $\mathrm{ER}^{+} \mathrm{PR}^{-}$status. Tumor size was significantly reduced from pretreatment $(39.37 \pm 10.63 \mathrm{cms})$ to post-treatment $(23.87 \pm 7.51 \mathrm{cms})(\mathrm{p}<0.05)$.

Conclusion: On the basis of this study it was concluded that ER, PR and Her-2/neu status changes on IHC staining after NACT. So, IHC analysis on a post treatment tissue block should be repeated before planning adjuvant chemotherapy in patients of carcinoma breast.

Copy Right, IJAR, 2019,. All rights reserved.

\section{Introduction:-}

Breast cancer accounts for $11.6 \%$ of all newly occurring cancers worldwide and represents $6.6 \%$ of all cancer deaths in both sexes while it accounts for $29 \%$ newly diagnosed cancers and $14 \%$ cancer related death exclusively in women. [1,2] Breast cancer has ranked number one cancer among Indian females with age-adjusted rate as high as

Corresponding Author:-Saumya Singh.

Address:-Department of General Surgery; Department of Trauma Surgery; Department of Endocrine

Surgery, King George`s Medical University, UP, Lucknow, India. 
25.8 per 100,000 women and mortality 12.7 per 100,000 women. [3] The etiology of carcinoma breast is extremely complex and its onset and progression is a multistep process resulting from a series of changes in epigenetic, genetic, endocrine and external environmental factors. Breast cancer is a steroid hormone dependent tumor. Stratification of patients according to hormone (ER, PR) receptor status and nodal metastasis is of great therapeutic importance. [12,20] For carcinoma breast, traits such as ER, PR status, Her 2 / neu expression and tumour histologic grade have already been well established as important prognostic indicator which can guide therapeutic decision. [20] The use of neoadjuvant chemotherapy for treatment of breast tumour raises some interesting questions. [16] One issue is that changes in the biological activity of a malignant neoplasm after exposure to chemotherapy could have important implication for patients receiving neoadjuvant treatment if further therapeutic decision is based on a pretreatment specimen. [13,14,19]

About $60 \%$ of human breast tumors contain detectable amounts of either ER or PR or both. Male breast cancer is almost always ER positive. The presence of ER predicts clinical response to all types of endocrine therapy, both additive and ablative. $[10,17]$ The presence of both receptors in a tumour is associated with almost an $80 \%$ chance of favorably responding to hormone addition or blockade. [11, 18] Her-2/neu is a member of the EGFr family of growth factors in which ligand binding results in receptor homodimerization and tyrosine phosphorylation by tryosine kinase domains within the receptor. Her-2/neu is both an important prognostic factor and predictive factors in breast cancer. If overexpressed Her-2/neu promotes enhanced growth and proliferation, and increases invasive and metastatic capabilities. [15] This study was designed to assess the effect of neoadjuvant chemotherapy on ER, PR status and Her-2/neu expression in breast cancer patients from North Indian population suffering from breast cancer coming to our OPD clinic (Department of Surgery) in collaboration with the Department of Pathology KGMU, UP, Lucknow.

\section{Patients and Method:-}

Patients suffering from breast cancer attending OPD at Department of General Surgery, KGMU for a period of 12 months i.e. from August 2011 to July 2012 were taken after their informed consent. Initially, 80 patients of invasive breast cancer which have underwent Primary systemic therapy (NACT) at the Department of General Surgery were included in this prospective observational study, but later on 9 patients were excluded from the study as they developed stage IV (Lung or Liver metastasis) disease. The remaining 71 patients were documented in detail and included in the present study.

Eligibility criteria for preoperative chemotherapy included no previous chemotherapy/hormone therapy, measurable lesions, WBC's > 4000/mm3, PC $\geq 1$ lac/mm3, SGPT \& SGOT x upper limit of normal and bilirubin $\leq 3 \mathrm{mg} / 100$ $\mathrm{ml}$. Patients with metastatic disease, cardiac disease (CHF \& history of MI within previous 3 months), severe vascular disease or uncontrolled concomitant infections were excluded. Also, chest x-ray, abdominal ultrasound, bilateral mammography, bone scan, ECG and 2D-Echo were performed within 2 weeks from the treatment start. The study was conducted following approval of the internal review board of KGMU, Lucknow.

Clinicaly breast tumor size was measured in $\mathrm{cm}$ as cross product of maximum vertical and horizontal diameter, using a caliper and the size of any palpable axillary nodes were ascertained before the administration of each cycle of chemotherapy and before surgery.

The neoadjuvant chemotherapy response was evaluated pathologically. A blinded consultant pathologist reviewed all paired biopsy and surgical specimen.

The immunohistochemical (IHC) analysis was performed on both cut core biopsies and mastectomy specimen for each patients. Sections (3-5mm) mounted on poly-L-lysine slides were subjected to IHC. The primary antibodies, diluted in Tris- $\mathrm{HCl}(\mathrm{pH} 7.5)$ were applied. Chromogen used was DAB (3,3' diaminobenzidine). The slides after counterstained for 10 second were mounted for examination. For assessment of ER and PR status, the percentage of cells (considered positive when $\geq 1 \%$ of stained nuclei was found in 10 high power fields) with nuclear reactivity was recorded. Only membranous staining was evaluated for Her-2/neu expression. It was then scored semiquantitatively using the $0-3+$ score (0: no staining or membrane staining in $<10 \%$ of tumour cells, $1: \geq 10 \%$ of tumour cells with weakly positive incomplete membrane staining. $2+: \geq 10 \%$ of tumour cells with weak to moderate staining of the entire membrane, $3+: \geq 10 \%$ of tumour cells with strong staining of the entire membrane. 
Statistical Analysis:

Clinical analysis of data collected during period of current study was done using chi - square test and Mc-nemar test. P value $<0.05$ was considered statistically significant. Analysis was done using SPSS software v 18.

\section{Results:-}

Clinico-pathologic and demographic attributes of the patients have been summarized in the table given below.

\begin{tabular}{|c|c|c|}
\hline \multicolumn{3}{|c|}{ Clinico-pathological characteristics of patients and tumor } \\
\hline Attributes & \multicolumn{2}{|l|}{ Cases(n=71) } \\
\hline $\begin{array}{l}\text { Age } \\
<40 \\
41-60 \\
>60\end{array}$ & $\begin{array}{l}26 \\
41 \\
4\end{array}$ & $\begin{array}{l}36 \% \\
58 \% \\
6 \%\end{array}$ \\
\hline $\begin{array}{l}\text { Sex } \\
\text { Male } \\
\text { Female }\end{array}$ & $\begin{array}{l}1 \\
70\end{array}$ & $\begin{array}{l}1.4 \% \\
98.6 \%\end{array}$ \\
\hline $\begin{array}{l}\text { Menopausal Status } \\
\text { Premenopausal } \\
\text { Postmenopausal }\end{array}$ & $\begin{array}{l}34 \\
36 \\
\end{array}$ & $\begin{array}{l}47.9 \% \\
52.1 \%\end{array}$ \\
\hline $\begin{array}{l}\text { Age at first pregnancy } \\
<20 \\
>21 \\
\text { Nulliparous }\end{array}$ & $\begin{array}{l}52 \\
16 \\
2\end{array}$ & $\begin{array}{l}73.2 \% \\
22.5 \% \\
2.8 \%\end{array}$ \\
\hline $\begin{array}{l}\text { Obesity } \\
\text { Obese } \\
\text { Non- Obese }\end{array}$ & $\begin{array}{l}7 \\
64\end{array}$ & $\begin{array}{l}9.9 \% \\
90.1 \%\end{array}$ \\
\hline $\begin{array}{l}\text { Laterality of Tumor } \\
\text { Bilateral } \\
\text { Left } \\
\text { Right }\end{array}$ & $\begin{array}{l}1 \\
33 \\
37\end{array}$ & $\begin{array}{l}1.4 \% \\
46.5 \% \\
52.1 \%\end{array}$ \\
\hline $\begin{array}{l}\text { TNM (Pre NACT) } \\
\text { IIB } \\
\text { IIIA } \\
\text { IIIB } \\
\text { IIIC }\end{array}$ & $\begin{array}{l}1 \\
8 \\
58 \\
4 \\
\end{array}$ & $\begin{array}{l}1.4 \% \\
11.3 \% \\
81.7 \% \\
5.6 \% \\
\end{array}$ \\
\hline $\begin{array}{l}\text { TNM (Post NACT) } \\
\text { IIA } \\
\text { IIB } \\
\text { IIIA } \\
\text { IIIB }\end{array}$ & $\begin{array}{l}1 \\
5 \\
12 \\
52\end{array}$ & $\begin{array}{l}1.4 \% \\
7.0 \% \\
16.9 \% \\
73.3 \%\end{array}$ \\
\hline $\begin{array}{l}\text { Tumor Size (Mean } \pm \text { SD) } \mathrm{mm} \\
\text { Pre-NACT } \\
\text { Post-NACT }\end{array}$ & $\begin{array}{l}39.37 \pm 10.63 \\
23.87 \pm 7.51\end{array}$ & \\
\hline $\begin{array}{l}\text { HPE } \\
\text { Invasive Ductal Carcinoma } \\
\text { Squamous Cell Carcinoma }\end{array}$ & $\begin{array}{l}70 \\
1\end{array}$ & $\begin{array}{l}98.6 \% \\
1.4 \%\end{array}$ \\
\hline $\begin{array}{l}\text { Grade } \\
\text { II } \\
\text { III }\end{array}$ & $\begin{array}{l}22 \\
49 \\
\end{array}$ & $\begin{array}{l}31 \% \\
69 \% \\
\end{array}$ \\
\hline Estrogen Receptor & & \\
\hline
\end{tabular}




\begin{tabular}{|l|l|l|}
\hline Positive & 21 & $29.6 \%$ \\
Negative & 50 & $70.4 \%$ \\
\hline Progesterone Receptor & & \\
Positive & 22 & $31.0 \%$ \\
Negative & 49 & $69.0 \%$ \\
\hline Her-2/neu & & $71.8 \%$ \\
Positive & 51 & $21.1 \%$ \\
Negative & 15 & $7.0 \%$ \\
Equivocal & 5 & \\
\hline Surgery (Mastectomy) & & $85.9 \%$ \\
Done & 61 & $14.1 \%$ \\
Not Done & 10 & $14.1 \%$ \\
\hline NACT Regimen & 10 & $56.3 \%$ \\
CAF & 40 & $29.6 \%$ \\
CEF & 21 & \\
TAC & & $38.0 \%$ \\
& Radiotherapy & $62.0 \%$ \\
Given & 27 & \\
Not Given & 44 & \\
\hline *C Cyclophosphamide; A= Adriamycin; F= 5-Fluorouracil; T= Taxanes; & \\
ER/PR and Her/2-neu Status : Pre- NACT & \\
\hline
\end{tabular}

The mean (SD) age of the patients was $46.66( \pm 10.89)$ years. About one third of them were between 41-50 years (32.4\%) followed by 31-40 (29.6\%), 51-60 (25.4\%), 20-30 (7\%) and >60 years (5.6\%). Majority of the patients were females $(98.6 \%)$ and there was one male patient $(1.4 \%)$

More than half $(57.7 \%)$ of the patients had age of menarche 13 years and $36.6 \%$ had 12 years. The parity was P3+0 among $16.9 \%$ of the patients and $\mathrm{P} 3+1 \& \mathrm{P} 4+2$ parity was among $15.5 \%$. However, $\mathrm{P} 2+1$ was found in $11.3 \%$ of the patients. Other parity was less than $10 \%$. Majority of the patient's breastfed (95.8\%).

About half $(47.9 \%)$ of the patients were in pre-menopause. The age of menopause was 48 years in $16.9 \%$ of the patients and 45 years in $14.1 \%$ patients. More than one third (40.8\%) of the patients had first pregnancy at the age $<18$ years and $32.4 \%$ between $18-20$ years. However, $22.5 \%$ of the patients had first pregnancy at the age $>20$ years .The mean BMI of the patients was $25.46 \pm 2.37$. None of the patients had family history of breast cancer. About half $(52.1 \%)$ of the patients had right side of breast cancer followed by left (46.5\%) and both (1.4\%). Majority (98.6\%) of the patients had Invasive Ductal Carcinoma (IDC). More than half of the patients had grade III (69\%) followed by grade II (31\%) on HPE.

\section{Hormone Receptor Status \& Immunohistochemistry \\ Estrogen Receptor (ER)}

Pre-NACT, ER was positive in $29.6 \%$ of the patients (Fig.1), who became $28.2 \%$ in post treatment and this change was statistically insignificant. 
Fig 1:-Estrogen Receptor +++ in $100 \%$ cells

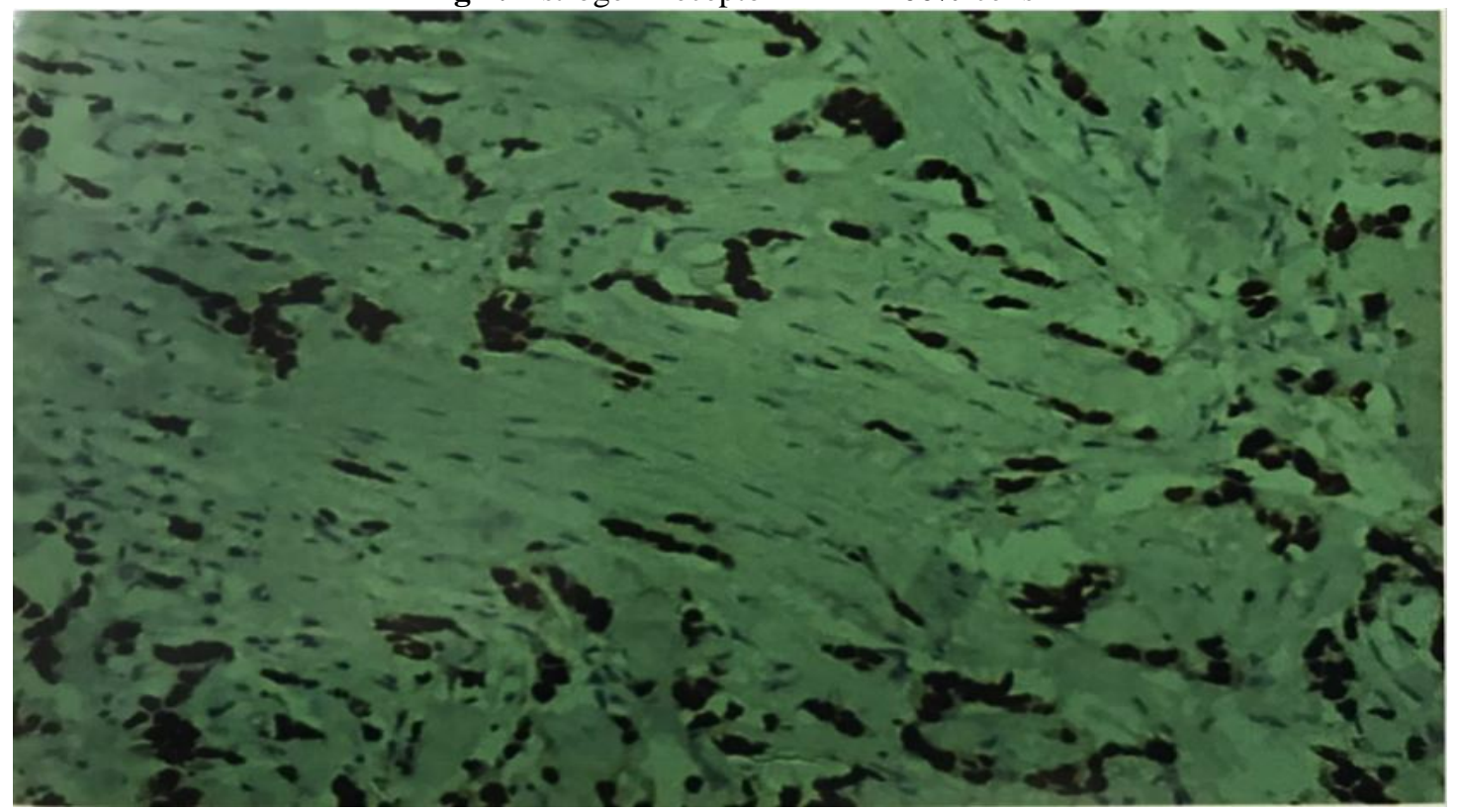

\section{Progesterone receptor (PR)}

Pre-NACT, PR was positive in $31.0 \%$ of the patients,(Fig. 2) who became $28.2 \%$ in post treatment and this change was statistically insignificant.

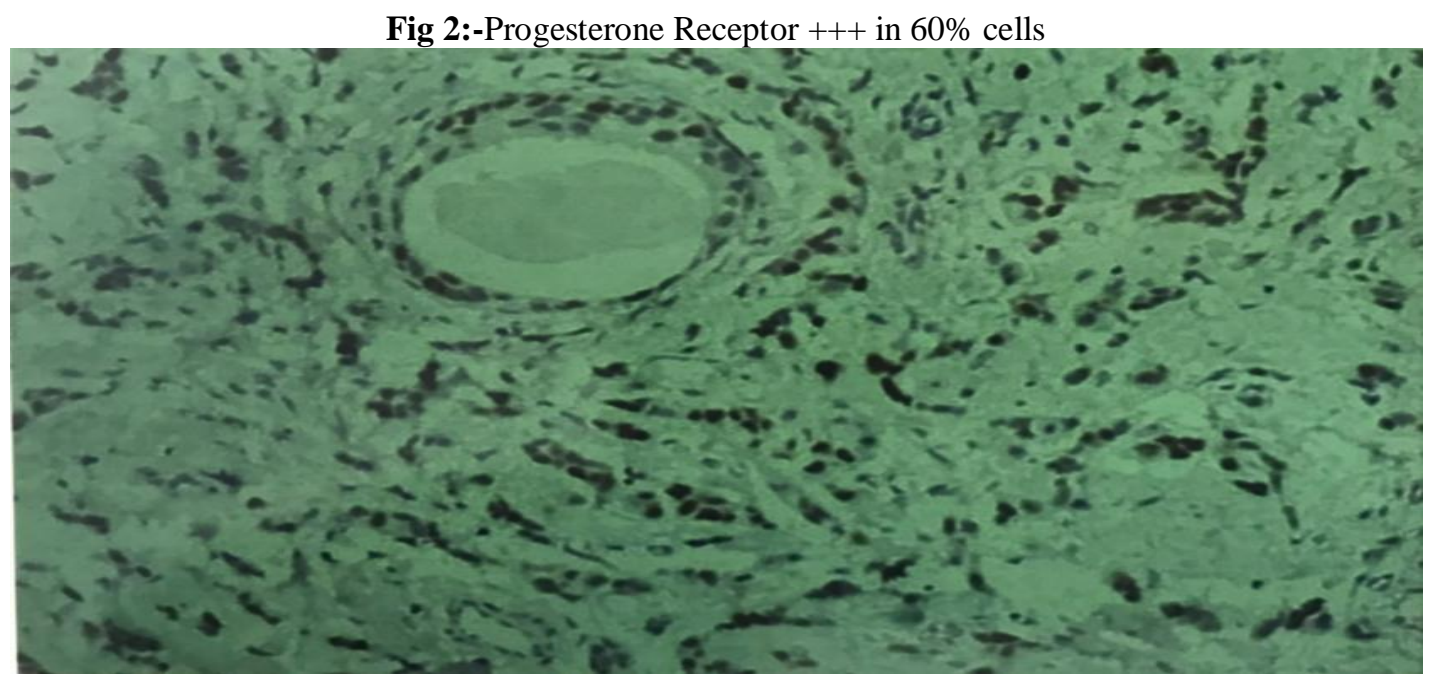

HER-2/NEU was positive in $71.8 \%$ of the patients before treatment, (Fig. 3) which became $70.4 \%$ in post treatment and this change was statistically insignificant.

The tumor size was significantly $(\mathrm{p}<0.05)$ reduced from pre treatment $(39.37 \pm 10.63)$ to post treatment $(23.87 \pm 7.51)$ $\mathrm{p}<\mathbf{0 . 0 5}$ (paired t-test). The dissected lymph node was $10.93 \pm 4.27$ and lymph node positive was $2.62+2.63$. The surgery was done in $85.9 \%$ of the patients. 
Fig 3:-Her/2-neu receptors 200X

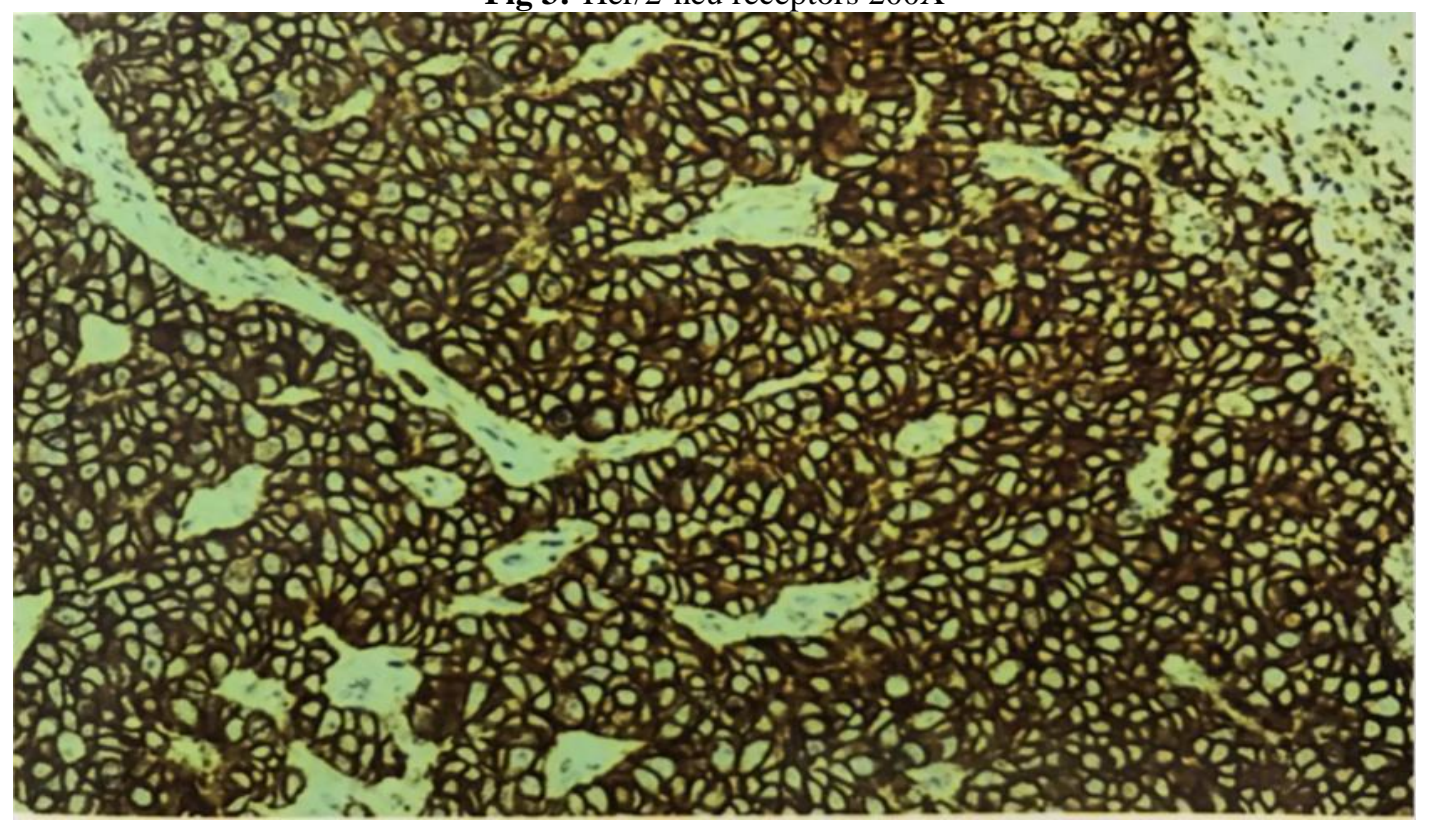

The CEF was given to $56.3 \%$ of the patients and TAC was given to $29.6 \%$. CAF was given to $14.1 \%$ of the patients. The radiotherapy was given to $38 \%$ of the patients

\section{Pre-NACT TNM}

T4bN1M0 was found in $62 \%$ of the patients and T4bN0M0 in $14.1 \%$. The other stages were found to be below 10\%.(Fig. 4)

\section{Post-NACT TNM}

T4bN0M0 and T4bN1M0 was found to be $45.1 \%$ and $28.2 \%$ of the patients respectively. T3N1M0 was seen in $16.9 \%$ of the patients after the treatment.

Fig 4:-TNM Pre-NACT and Post-NACT

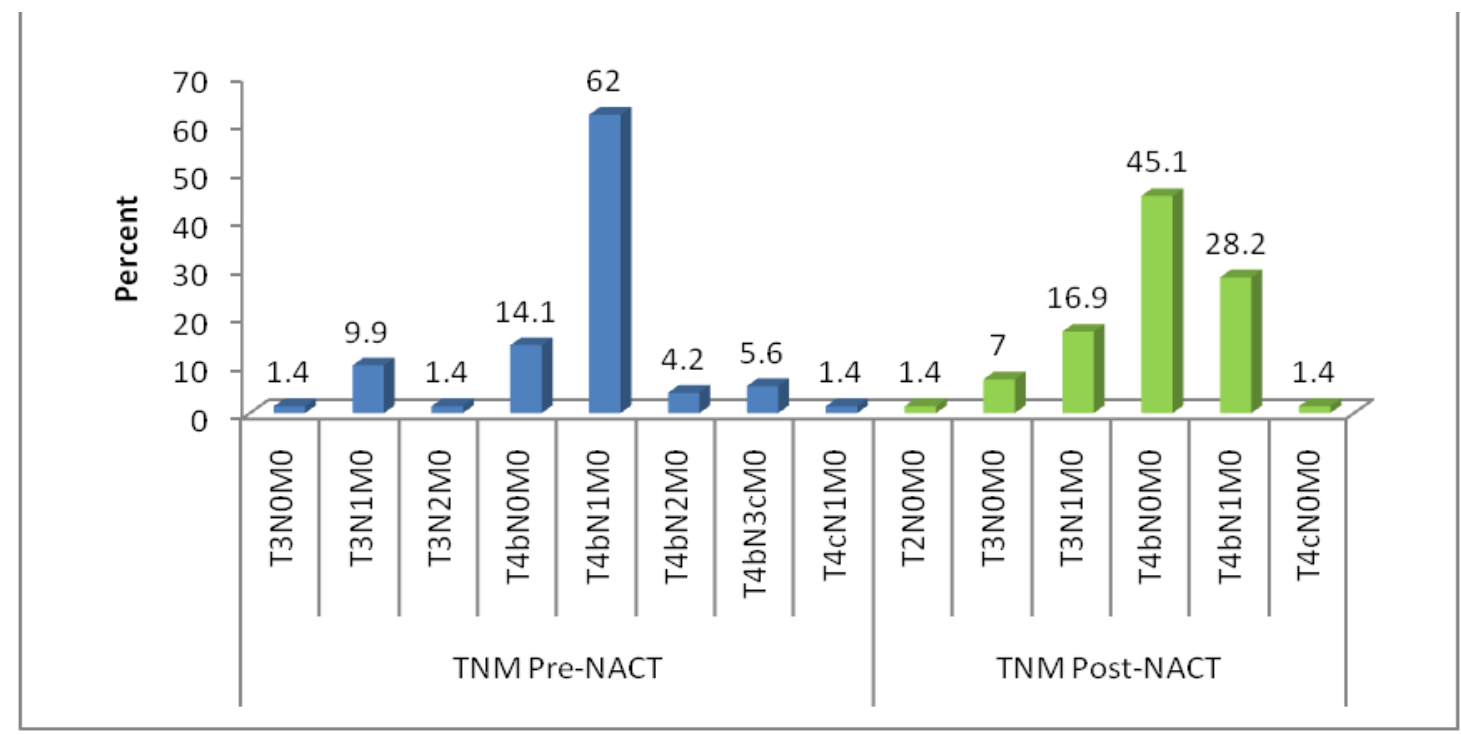


Fig 5:-Lymphnode metastasis

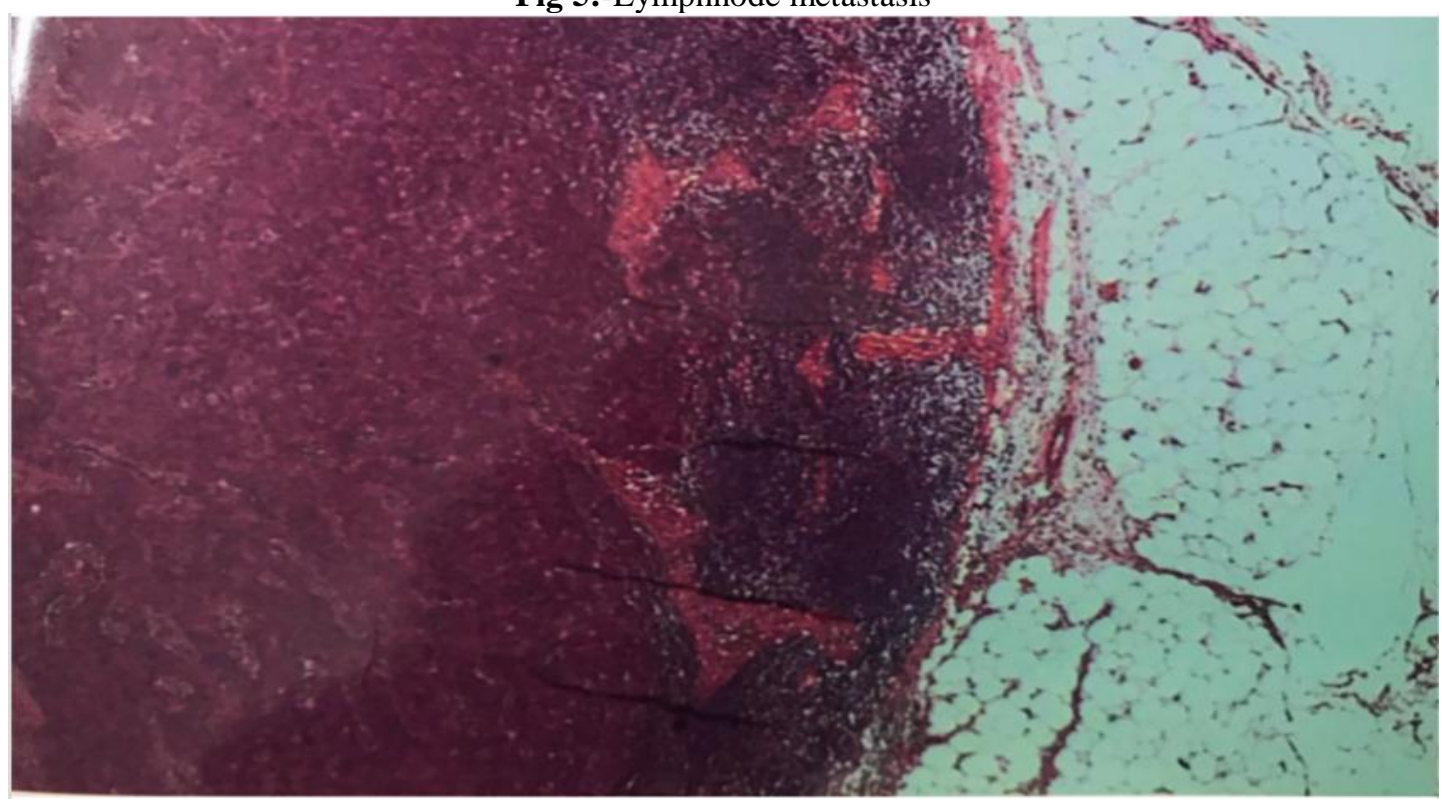




\section{Combination of ER and PR}

The ER +ve and PR+ve was seen in $26.8 \%$ of the patients before the treatment which became $25.4 \%$ after the treatment. However, ER-ve and PR-ve was found to be $66.2 \%$ before the treatment which became $69 \%$ after the treatment.(Fig. 6)

Fig 6:-Combination of ER and PR, Pre and Post- NACT

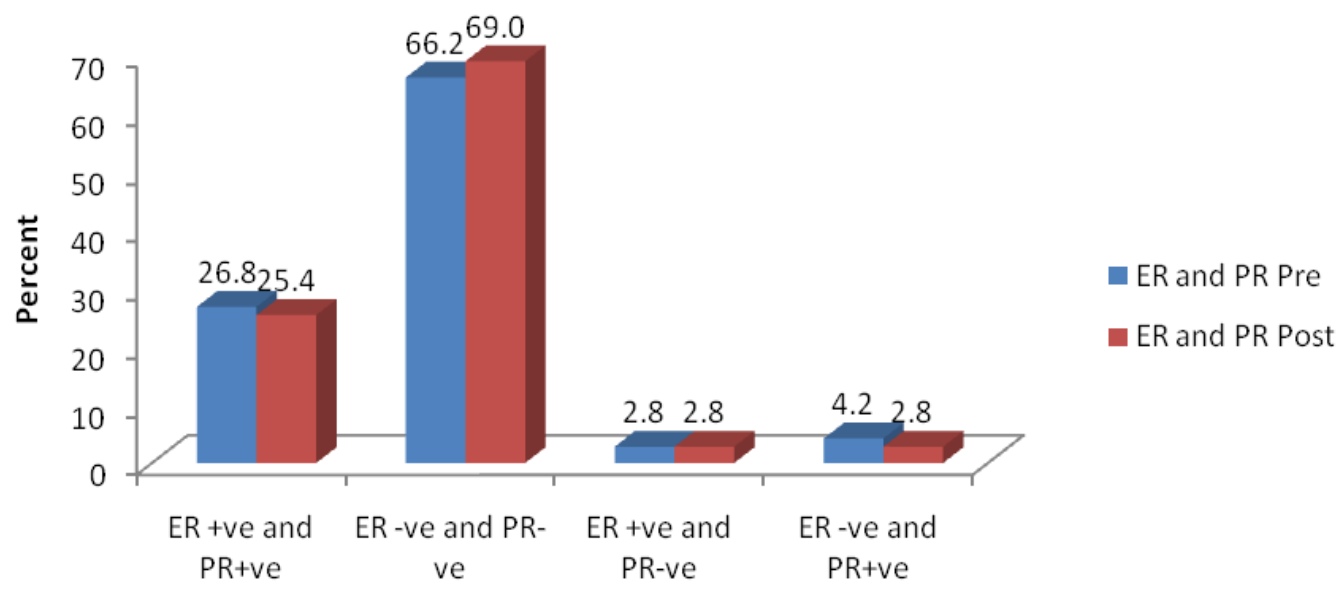

Combination of ER, PR and HER-2/neu +ve

ER +ve, PR+ve and HER-2/neu +ve was $29.4 \%$ before the treatment which became $26 \%$ after the treatment. ER -ve , PR-ve HER-2/neu and +ve was $62.7 \%$ before the treatment and became $68 \%$ after the treatment. (Fig. 7 )

Fig 7:-Combination of ER, PR and HER-2/neu+ve

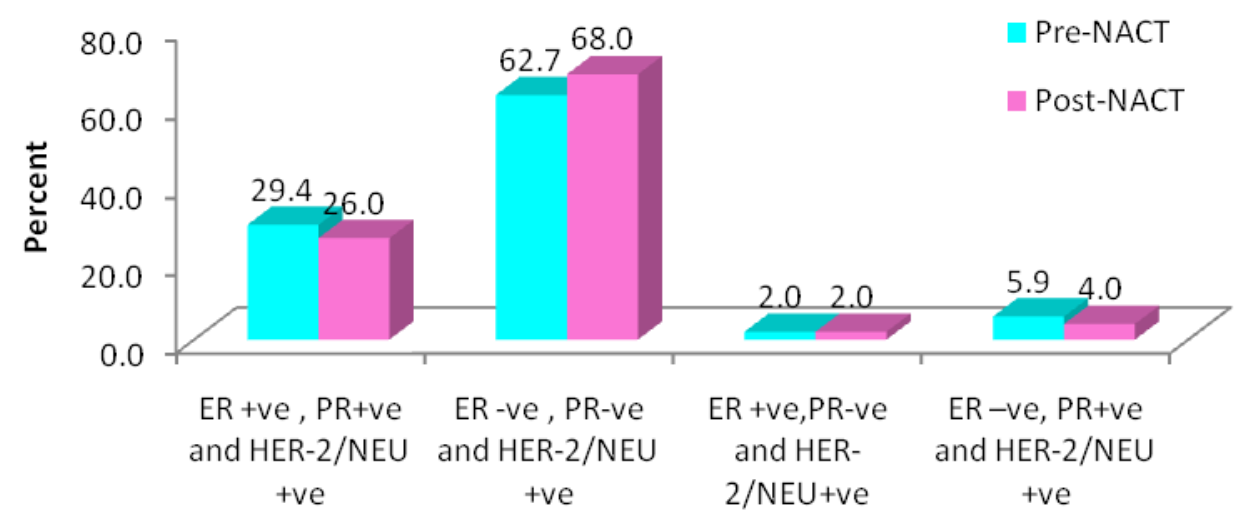

\section{Combination of ER, PR and HER-2/neu -ve}

$\mathrm{ER}+\mathrm{ve}, \mathrm{PR}+\mathrm{ve}$ and HER-2/neu -ve was $5.6 \%$ before the treatment and remained the same after the treatment. ER ve and PR-ve HER-2/neu-ve was $14.1 \%$ before the treatment and became $15.5 \%$ after the treatment. (Fig. 8) 
Fig 8:-Combination of ER, PR and HER-2/neu -ve

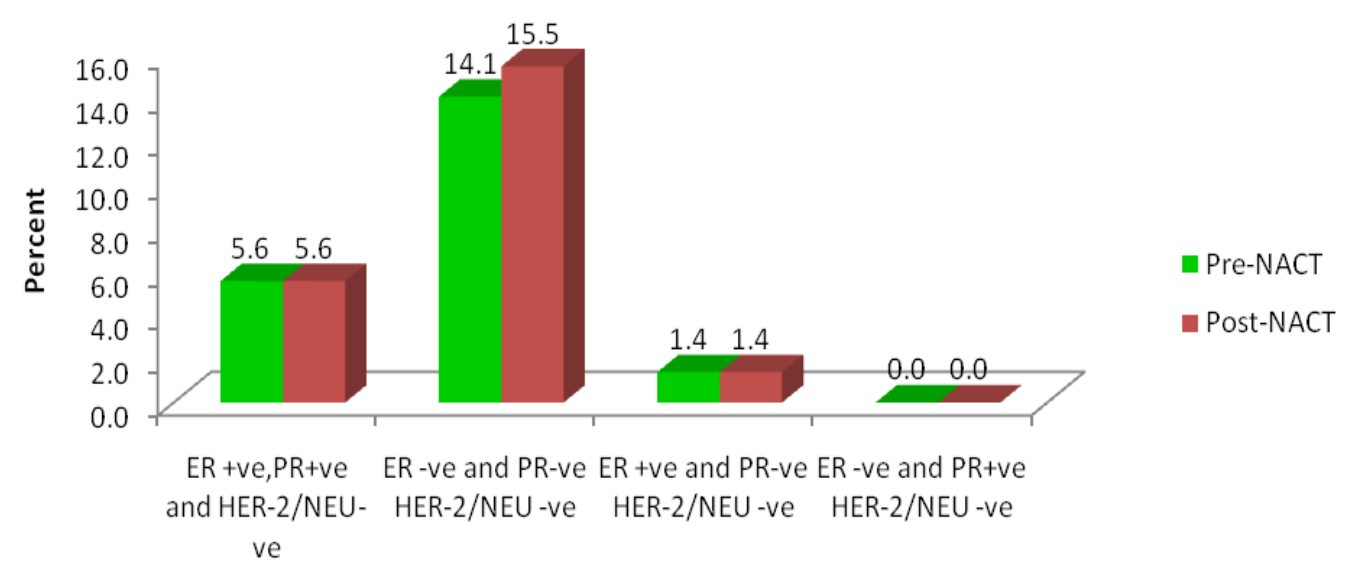

\section{Discussion:-}

The present study reports an analysis of change of hormone receptor status and Her-2/neu expression after neoadjuvant chemotherapy on a cross section of patients with cancer breast, admitted in the Department of General Surgery in KGMU, Lucknow from August 2011 to July 2012.

The effect of NACT on tumour markers, more specifically ER, PR and Her-2/neu was investigated in the present study in view of the fact that there is no such study published in North India till date.

Arens et al. in a study $(\mathrm{n}=25)$ reported no significant differences in expression patterns of ER or PR following NACT when compared with matched control. In both the groups, there were rare cases in which hormone receptor expression changed in the final surgical specimen when compared with the initial core biopsy; these changes did not meet statistical significance. [4]

In a series of 214 patients treated with chemotherapy prior to surgery, $14 \%$ demonstrated a statistically significant loss of expression of ER in the post-treatment final surgical specimen, with 51.7\% showing a significant loss of PR expression when compared with matched controls; according to Taucher et al. [5] Additionally, the untreated control group in this study showed a non-significant decrease in ER and/or PR expression. Overall, the onset of menopause induced by preoperative chemotherapy was hypothesized to explain this decrease in ER but not PR expression. Furthermore, Kasami et al. found a statistically significant negative change in PR status in $28.8 \%$ of patients $(\mathrm{n}=173)$ and no significant change in ER following neoadjuvant chemotherapy. [6] The alteration of PR expression without change in ER status observed after neoadjuvant chemotherapy is of undetermined clinical significance, as ER is generally considered a stronger predictor of response to hormone directed therapy. Overall, determination of both a pre-treatment and post-treatment PR IHC profile is merited due to the possible change in PR expression following neoadjuvant chemotherapy. Further research is needed in order to examine the biological interaction of cytotoxic agents with steroid hormone receptors, the reproducibility of results with matched controls.

Neoadjuvant treatment has become a standard therapeutic option in case of primary breast cancer. Taucher et al. reported a significant difference in ER and PR expression after NAC. Kasami et al reported changes in PR but not in ER. A possible explanation of these differences may be related to the different types of drugs used in NAC. Kasami et al. and Taucher et al used different chemotherapy regimens whereas the women in the present group were given primary anthracycline and taxane based chemotherapy. In our study 40 (56.3\%), 21 (29.6\%), 10 (14.1\%) out of 71 patients received CEF, TAC and CAF neoadjuvant chemotherapy respectively. Further more, another possible reason for this discrepancy may be related to the statistical analysis. Kasami et al used the Mannwhitney test instead of the McNemar's test. In our case, we have used McNemar's test and Chi-square test. Our findings show that Her2/neu expression changes after NACT. One patient changed its expression from Her-2/neu positive to negative postNACT and another changed its expression from Her-2/neu negative to positive $(\mathrm{p}=0.97)$ which was statistically insignificant. Similar findings reported by Piper et al, who reported a change in Her-2/neu marker expression in $25.7 \%$ of a sample of 35 cases with partial tumour response to NAC. [7] 
In our study 51(71.8\%) were Her-2/neu positive pre-neoadjuvant therapy, changed their expression to 50(70.4\%) post chemotherapy. Neoadjuvant therapy resulted in a significant decrease in mitotic count and an increase in the proportion of patients with Her-2/neu over expression.

In our study, 21 out of 72 cases (29.6\%) and 22 out of 71 cases (31.0\%) were respectively ER positive and PR positive. 51(71.8\%), 15(21.1\%) and 5(7\%) out of 71 analysed cases were respectively Her-2/neu positive, negative and equivocal by IHC assay.

In our series, Her-2/neu staining changed after chemotherapy. 51 out of $71(71.8 \%)$ were Her-2/neu positive, but post chemotherapy only $50(70.4 \%)$ remained so. 15 out of $71(21.1 \%)$ were Her-2/neu negative and increased to 16 (22.5\%) post chemotherapy.

This is in contrast with earlier observations that Her-2 status remains unchanged after Primary systemic therapy (Bottini et al, Taucher et al, RJ Burcombe et al). [5,8,9] Based on our data, it is recommended that patients with moderate or strong staining should undergo IHC analysis on a post treatment tissue block to determine the post chemotherapy Her-2 status. Out of 7 out of the 71 tumors, which changed receptor status, few negative staining on pretreatment core biopsies was scored positive after chemotherapy and few hormone receptor-positive core biopsies stained negative after chemotherapy.

\section{Conclusion:-}

Concluding this study, it was found that ER, PR and Her-2/neu status changes on IHC staining after NACT. So, IHC analysis on a post treatment tissue block should be repeated in a selected subgroup before planning adjuvant chemotherapy in patients of carcinoma breast. Further studies based on large sample size and long term follow up are required to validate the clinical relevance of changes of hormonal receptor status and its role in prognostication and selection of adjuvant therapy.

\section{Conflicts of interest}

The authors have no conflicts on interest to declare.

\section{References:-}

1. Bray F, Ferlay J, Soerjomataram I, Siegel RL, Torre LA, Jemal A. Global cancer statistics 2018: GLOBOCAN estimates of incidence and mortality worldwide for 36 cancers in 185 countries. CA: a cancer journal for clinicians. 2018 Nov;68(6):394-424.

2. Siegel R, Naishadham D, Jemal A. Cancer statistics, 2013. CA Cancer J Clin. 2013; 63:11-30.

3. Malvia S, Bagadi SA, Dubey US, Saxena S. Epidemiology of breast cancer in Indian women. Asia-Pacific Journal of Clinical Oncology. 2017 Aug;13(4):289-95.

4. Arens N, Bleyl U, Hildenbrand R. HER2/neu, p53, Ki67, and hormone receptors do not change during neoadjuvant chemotherapy in breast cancer. Virchows Archiv. 2005 May 1;446(5):489-96.

5. Taucher S, Rudas M, Gnant M, Thomanek K, Dubsky P, Roka S, Bachleitner T, Kandioler D, Wenzel C, Steger G, Mittlb M. Sequential steroid hormone receptor measurements in primary breast cancer with and without intervening primary chemotherapy. Endocrine-related cancer. 2003 Mar 1;10(1):91-8.

6. Kasami M, Uematsu T, Honda M, Yabuzaki T, Sanuki J, Uchida Y, Sugimura H. Comparison of estrogen receptor, progesterone receptor and Her-2 status in breast cancer pre-and post-neoadjuvant chemotherapy. The Breast. 2008 Oct 1;17(5):523-7

7. Piper GL, Patel NA, Patel JA, Malay MB, Julian TB. Neoadjuvant chemotherapy for locally advanced breast cancer results in alterations in preoperative tumor marker status. The American surgeon. 2004 Dec 1;70(12):1103.

8. Bottini A, Berruti A, Bersiga A, Brunelli A, Brizzi MP, Marco BD, Cirillo F, Bolsi G, Bertoli G, Alquati P, Dogliotti L. Effect of neoadjuvant chemotherapy on Ki67 labelling index, c-erbB-2 expression and steroid hormone receptor status in human breast tumours. Anticancer research. 1996;16(5B):3105-10.

9. Burcombe RJ, Makris A, Richman PI, Daley FM, Noble S, Pittam M, Wright D, Allen SA, Dove J, Wilson GD. Evaluation of ER, PgR, HER-2 and Ki-67 as predictors of response to neoadjuvant anthracycline chemotherapy for operable breast cancer. British journal of cancer. 2005 Jan;92(1):147.

10. Colleoni M, Montagna E. Neoadjuvant therapy for ER-positive breast cancers. Annals of Oncology. 2012 Sep 1;23(suppl_10):x243-8. 
11. Patnayak R, Jena A, Rukmangadha N, Chowhan AK, Sambasivaiah K, Phaneendra BV, Reddy MK. Hormone receptor status (estrogen receptor, progesterone receptor), human epidermal growth factor-2 and p53 in South Indian breast cancer patients: A tertiary care center experience. Indian journal of medical and paediatric oncology: official journal of Indian Society of Medical \& Paediatric Oncology. 2015 Apr;36(2):117.

12. Yang L, Zhong X, Pu T, Qiu Y, Ye F, Bu H. Clinical significance and prognostic value of receptor conversion in hormone receptor positive breast cancers after neoadjuvant chemotherapy. World journal of surgical oncology. 2018 Dec;16(1):51.

13. Hirata T, Shimizu C, Yonemori K, Hirakawa A, Kouno T, Tamura K, Ando M, Katsumata N, Fujiwara Y. Change in the hormone receptor status following administration of neoadjuvant chemotherapy and its impact on the long-term outcome in patients with primary breast cancer. British journal of cancer. 2009 Nov;101(9):1529.

14. Pedrini JL, Savaris RF, Schorr MC, Cambruzi E, Grudzinski M, Zettler CG. The effect of neoadjuvant chemotherapy on hormone receptor status, HER2/neu and prolactin in breast cancer. Tumori Journal. 2011 Nov;97(6):704-10.

15. Ramteke P, Seenu V, Prashad R, Gupta SD, Iyer V, Deo SV, Gogia A, Mathur S. Alteration in steroid hormone and Her-2/neu receptor status following neoadjuvant chemotherapy in locally advanced breast cancer: Experience at a tertiary care centre in India. Indian journal of cancer. 2016 Jul 1;53(3):366.

16. Kaufmann M, Hortobagyi GN, Goldhirsch A, Scholl S, Makris A, Valagussa P, Blohmer JU, Eiermann W, Jackesz R, Jonat W, Lebeau A. Recommendations from an international expert panel on the use of neoadjuvant (primary) systemic treatment of operable breast cancer: an update. Journal of Clinical Oncology. 2006 Apr 20;24(12):1940-9.

17. Burstein HJ, Griggs JJ, Prestrud AA, Temin S. American society of clinical oncology clinical practice guideline update on adjuvant endocrine therapy for women with hormone receptor-positive breast cancer. Journal of oncology practice. 2010 Aug 6;6(5):243-6.

18. Tacca O, Penault-Llorca F, Abrial C, Mouret-Reynier MA, Raoelfils I, Durando X, Achard JL, Gimbergues P, Cure H, Chollet P. Changes in and prognostic value of hormone receptor status in a series of operable breast cancer patients treated with neoadjuvant chemotherapy. The oncologist. 2007 Jun 1;12(6):636-43.

19. Van de Ven S, Smit VT, Dekker TJ, Nortier JW, Kroep JR. Discordances in ER, PR and HER2 receptors after neoadjuvant chemotherapy in breast cancer. Cancer treatment reviews. 2011 Oct 1;37(6):422-30.

20. Adams AL, Eltoum I, Krontiras H, Wang W, Chhieng DC. The effect of neoadjuvant chemotherapy on histologic grade, hormone receptor status, and HER2/neu status in breast carcinoma. The breast journal. 2008 Mar;14(2):141-6.

21. Goldhirsch A, Winer EP, Coates AS, Gelber RD, Piccart-Gebhart M, Thürlimann B, Senn HJ, Panel members, Albain KS, André F, Bergh J. Personalizing the treatment of women with early breast cancer: highlights of the St Gallen International Expert Consensus on the Primary Therapy of Early Breast Cancer 2013. Annals of oncology. 2013 Aug 4;24(9):2206-23.

22. Goldhirsch A, Wood WC, Coates AS, Gelber RD, Thürlimann B, Senn HJ, Panel Members. Strategies for subtypes - dealing with the diversity of breast cancer: highlights of the St Gallen International Expert Consensus on the Primary Therapy of Early Breast Cancer 2011. Annals of oncology. 2011 Jun 27;22(8):173647. 